germinal layers, namely, cartilage, nerve, lymphoid tissue, fat, involuntary and heart muscle, skin, hair follicles, vascular tissue with melanoblasts, small intestine, liver, and parathyroid. The eyeball and the optic nerve are normal and are independent of the origin of the tumour.

Diagnosis.-True filial teratoma of the left orbit.

In this case certain cells of the developing embryo had taken on independent growth after being segregated in the left orbit and this must have taken place relatively late in intra-uterine life as the development of the eye and optic nerve had already taken place.

I am indebted to Lt.-Col. H. Shortt, I.M.S., Director of the $\frac{O}{0}$. Central Research Institute, India, for the micro-photographs, and $\frac{\overrightarrow{0}}{\circ}$ to Capt. S. K. Roy, Surgeon to the Mavo Hospital, Calcutta, for bringing the case to me.

\title{
BIBLIOGRAPHY
}

Mizuo.-Ber. u. d. 35st Versamml. d. Ophth. Gesellsch. z., Heidelberg, p. 347, I 1908. Arch. f. Augenheilk., Vol. LXV.

Ahlfeld.-Die Missbildungen d. Menschen. I Abschnitt, Leipzig. Taf. VI, Fig. 11, p. 52,1880

Broer and Weigert.-Virch. Arch;, Vol. LXVII, p. 518, 1876.

Courant.-Centralbl. f. Gynakologie, Vol. XVII, p. 740, 1893.

von Hippel.-Arch.f. Ophthal., Vol. LXIII, p. 1, 06.

Elliot and Ingraham.-Ophthalmoscope, December, 1910.

Holmes.-Trans. Path. Soc. Lond., Vol. XIV, p. 248, 1863.

Lawson.-Trans. Path. Soc. Lond., Vol. XXXV, p. 379, 1884.

Ewetsky.-Moscow Ophthal. Soc., Wratsch, Vol. XXI, p. 690, 1904; Nagel's Jahresbericht, p. 303, 1904. ?

Coulter and Coats.-Roy. Lond. Ophthal. Hosp. Reps., January, 1910

Corbett.-Boston Med. and Surg. Jl., Vol. CXCII, pp. 484-488, 1925.

Kearney.-Amer.Jl. of Ophthal., Vol. IX, p.416, 1926.

\section{POSTERIOR LENTICONUS (REPORT OF A CASE)*}

BY

T. H. LUO, M.D.

Among its congenital or developmental anomalies, the human
crystalline lens may present a conical bulging either on its anterior
or posterior surface. The anomaly is a rare ocular condition, and
according to the literature, the posterior type, lenticonus posterior, N
is more common than the anterior variety, lenticonus anterior.
Posterior lenticonus was first recognized and reported by Meyer
in 1888. Owing to mistakes in either diagnosis or classification

- From the Department of Ophthalmology of the Peiping Union Medical ${ }^{+}$ College, Peiping, China. 
many of the cases reported in the early days have been regarded with suspicion and placed in the group of so-called "false lenticonus." It is only with the use of the slit-lamp that cases of "false lenticonus" can be unmasked. Tyson ${ }^{2}$ in 1928 reduced the number of "true" cases reported to "about six." Since then, according to $\mathrm{Marsh}^{3}$, over 20 slit-lamp studies have been reported under this title though some of the slit-lamp diagnoses are not without suspicion.

In our clinic, most of the patients with pupillary opacities or impairment of vision which cannot be improved by manifest refraction are examined under a cycloplegic with the retinoscope or ophthalmoscope or slit-lamp or all three instruments. This seems sufficient safeguard against any escape of posterior lenticonus if it does occur. Still, the following case is the only one seen in this hospital.

Patient, a Chinese boy, aged 13 years, was brought to our eye clinic in August, 1934, for blurring of vision of both eyes for distance of about three years' duration. His eyes were apparently normal until about three years before, when (at the age of 10 years) he started to go to school and was discovered by his teachers to be short-sighted. Last year, his father, becoming very curious about his eyes, looked at them carefully and found some opacities in both pupillary areas. In the past the patient had had no ocular disease or injuries, no convulsions or serious general diseases. The patient's mother had similar lens opacities for which she came to the Peiping Union Medical College at the same time. Her eye condition was diagnosed to be congenital cataract complicated by a "cataract in osteomalacia." The mother's father and one of her sisters were also said to have been affected with lens opacities since childhood. As far as the parents could tell, the rest of the family members and relatives, except for near-sightedness, had no similar eye conditions.

General examination of the boy in our medical department revealed essentially normal physical findings. No congenital abnormalities could be found in other parts of the body. Blood calcium and phosphorus were within normal limits.

On ocular examination, the lids, conjunctiva, cornea, anterior chamber, iris and pupil were normal. In both pupillary areas there were greyish-white opacities, more extensive and dense in the left one, which appeared to the naked eye and loupe to be located in the posterior part of the lens. Vision of the right eye was $6 / 20$; of the left eye $6 / 30$, and could not be improved with lenses or pin-hole disc. Both eyes read Jaeger No. 1 at about $6 \mathrm{cms}$.

When the eyes were examined under homatropine dilatation the following findings were obtained. The left pupillary area showed a 
fairly big, central, roundish, dark greyish-blue opacity which gave no parallactic displacement on movement of the retinoscope. The opacity was surrounded by a narrow, peripheral clear zone which gave a red reflex. Retinoscopy of this eye was not possible. In the centre of the right pupil was a small dense opacity. The red reflex was fairly bright, but owing to irregular movements of the shadow retinoscopy was difficult. The lens that seemed to come closest to a "full correction" was $-3.0 \mathrm{D}$. sph. $-1.0 \mathrm{D}$. cyl. axis $75^{\circ}$ which did not improve the vision. The so-called "oil-drop phenomenon" was not present.

Fundi of both eyes were normal as seen through the periphery of the pupil. Tactile tension normal.

Under the slit-lamp, the real nature of the ocular condition came into view. The posterior surface of the left lens protruded unduly into the vitreous (Fig. 1). This protrusion was cup-shaped, the diameter of the cup being about three-fourths of the diameter of the lens and its depth being about one antero-posterior diameter of the lens proper. Its edge, the junction of the normal and abnormal posterior surface, was rounded off gradually like that of a basin. The walls of the conus were densely opaque, the opacity consisted grossly of two layers which were of a greyish-white, irregularly punctate appearance. From between the two edges opaque, radiating processes came out which reached almost the equator of the lens. With the narrow beam, the formation of the conus? seemed to start from the posterior peripheral band of the embryonic nucleus and the opacities involved this band and what was behind it. Owing to the density of the opacities, nothing could be seen through them. The lens substance within the conus was clear except for some isolated opaque stipplings near its walls. The rest of the lens was also clear. The anterior and posterior " $Y$ " sutures were, however, not visible. In the right lens there was an irregular-shaped opacity at the posterior pole of the embryonic nucleus (Fig. 2). The opacity was densest in the centre with a small and irregularly shallow depression on its anterior surface and gradually faded off toward the periphery (posterior polar cataract). The lens substance anterior and posterior to this region was clear. The "ring reflex" of Vogt and the "scissors reflex" of Marsh could not be demonstrated.

\section{Discussion}

What is a true posterior lenticonus? A comprehensive satisfactory definition is wanting. Collins and Mayou ${ }^{4}$ described posterior lenticonus as a protrusion backward of the lens substance through a gap in the capsule into the vitreous, or, if the capsule is only abnormally thin and not actually deficient, a bulging 


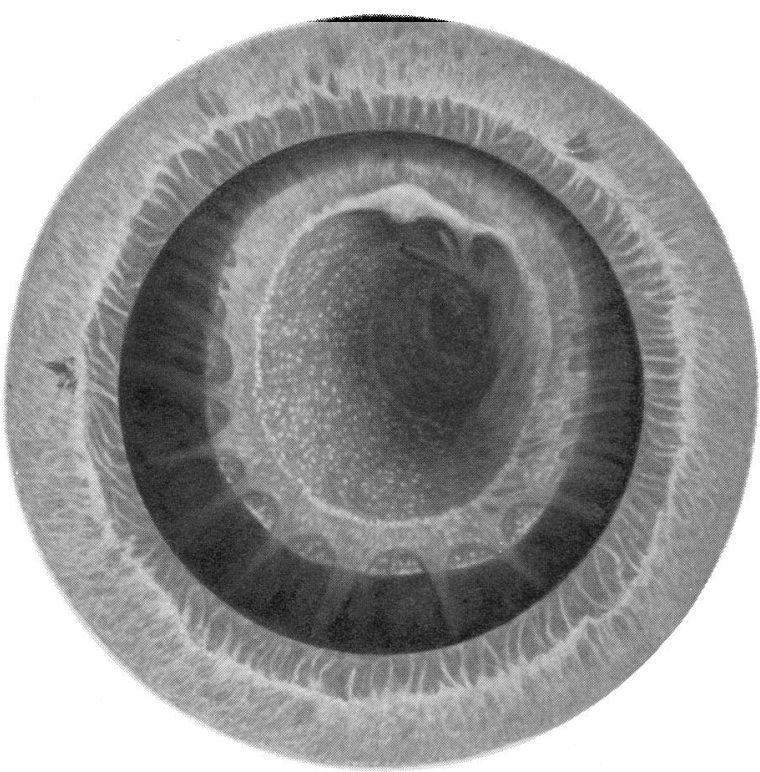

FIG. 1.

Posterior Lenticonus, left eye.

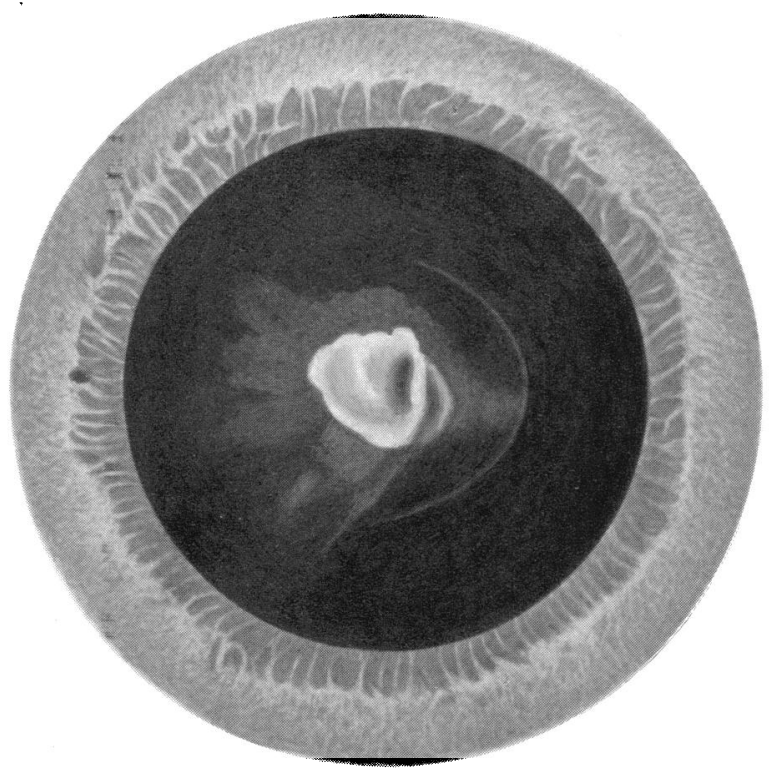

FIG. 2.

Posterior Polar Cataract, right eye. 
backward of the lens substance at the posterior pole. According to Colombo's definition ${ }^{5}$, a veritable posterior lenticonus requires the following characteristics: "A congenital lesion, without anterior lens changes connected with the conus, and absence of any tissue changes pointing to diseases or trauma . . . . a transparent, hemispherical, sharply-outlined prominence on the posterior pole." Marsh ${ }^{6}$, who recently brought the literature on this subject up to date, remarked that the former definition was indefinite and incomprehensive, while the latter, though the most exact one, was too specific and rigid. By comparing the reported cases, he offered a system of classification in which he divided the cases into four groups. Class I is Colombo's type form, a transparent hemispherical bulge set "like a skull cap" on the posterior pole of an otherwise normal lens. To Class II belong those cases which are otherwise typical, but show opacity at the bottom of the conus or irregularity in their form. Class III includes cases with a good lenticonus, but with related opacities or other changes in the lens substance. The uncertain, doubtful cases are put into Class IV. Besides these, he collected a small group of cases which are not veritable lenticonus, but might be confused with it and called these "quasi-lenticonus." If his classification is generally accepted, many definite cases of posterior lenticonus will not be excluded just because of having incidental or perhaps secondary changes.

The chief symptom which brings a patient with posterior lenticonus to an eye physician is the impairment or blurring of vision. Before the days of the slit-lamp the diagnostic signs were the so-called "oil-drop phenomenon" surrounded by a variable shadow, and the greatly increased myopia of the central part as compared with the periphery when the eyes were examined with the retinoscope or ophthalmoscope. Gullstrand ${ }^{7}$ in his study of the movement of the Purkinje images of the posterior lens surface demonstrated another valuable sign, i.e., the movement of the reflections on the posterior surface for determining the form and changes in its curvature. With the slit-lamp not only is the conus definitely seen, but its form and dimensions can be measured. The "ring reflex" of $\operatorname{Vog}^{8}$ has been considered a slit-lamp sign of the first importance and is probably expected to be present in every typical form of posterior lenticonus. Marsh, ${ }^{9}$ in 1927 , observed another slit-lamp phenomenon, "the scissors reflex," by using the narrow beam and also described the application of the dot beam, both of which, according to him, had not been mentioned by previous writers.

The origin of this unusual anomaly is unknown. Various speculative theories have been advanced, but not satisfactorily proved. These, Marsh has discussed extensively in his paper, 
and he also proposed a new theory of "accommodative strain" to account for the condition. A repetition of the same is therefore omitted here. The fact that in our case several members of the family have been affected with lens opacities since childhood, speaks for the conditions being a congenital anomaly. So far no clinically observed case has given opportunity for microscopical study and cases which have been microscopically studied have not been recognized during life.

In our case, without the aid of the slit-lamp, the condition could easily have passed for a posterior polar or cortical cataract, because the appearance to the naked eye was just that of a dense opacity situated in the deep parts of the lens and besides, the ophthalmoscopic "oil-drop phenomenon" was absent and a difference in refraction between the central part and the periphery could not be detected. The slit-lamp, however, very clearly revealed the presence of a posterior cone-shaped projection. In cases in which the opacities are especially pronounced, a lenticonus which is not very obvious is very difficult to diagnose, even with the aid of the slit-lamp. Reese's statement ${ }^{10}$ that "the greater the opacity, the more one is inclined to doubt the authenticity of the case," characterizes the situation very well. From the description of Butler's report ${ }^{11}$ the present case, except for detailso is essentially similar to his fourth one. Bothman's case ${ }^{12}$, though only briefly reported, seems also to be of the same type. Botlo these cases are placed bv Marsh in his IVth class of posterior lenticonus. If Marsh's classification is to be adopted, the present case, being unmistakably a true posterior lenticonus, could be listed only under his class III, although the opacities may appear not quite comparable with his description.

\section{LITERATURE}

1. Meyer, Ed.-Centralbl.f. Augenheilk., Vol. XII, p. 41, 1888.

2. Tyson, H. H.-Arch. of Ophthal., Vol. LVII, p. 38, 1928.

3. Marsh, E. J.-Arch. of Ophthal., Vol. VIII, p. 804, 1932.

4. Collins, E. T., and Mayou, M. S.-Pathology and Bacteriology of the Eye, Ed. 2. Philadelphia: P. Blakiston's Son \& Company, p. 45, 1925.

5. Colombo, G. L.-Ann. d'Ocul., Vol. CLXI, p. 364, 1924.

6. Marsh, E. J.-Ibid.

7. Gullstrand, A.-Svenska Läk 'Sällsk. Handl., Vol. XLVIII, p. 119, 1922.

8. Vogt. A.-Lehrbuch und Atlas der Spaltlampenmikroskopie des lebenden Auges, Vol. II, p. 449, 1931.

9. Marsh, E. J.-Arch. of Ophthal., Vol. LVI, p. 128, 1927.

10. Reese, W. S.-Trans. of the Amer. Ophthal. Soc., Vol. XVI, p. 339, 1928.

11. Butler, T. H.-Arch. of Ophthal., Vol. III, p. 425, 1930.

12. Bothman, Louis.-Amer. Jl. of Ophthal., Vol. XIV, p. 820, 1931. 